\title{
Eye-tracking v prostredí školskej triedy ${ }^{1}$
}

\author{
ZuZANA ŠMIDEKOVÁ
}

\begin{abstract}
Abstrakt: Predkladaný text predstavuje možnosti využitia technológie umožňujúcej sledovanie a zaznamenávanie pohybu oči - eye-trackingu - v pedagogickom výskume. Tvorený je kombináciou teoretickej stati približujúcej podstatu a mechanizmus očných pohybov, metódy ich sledovania a napokon samotnú technológiu eye-trackingu. Následne, $v$ druhej časti, sa text opiera o výsledky prehladovej śtúdie, ktoré sú prezentované dvojstupñovo. V prvom kole bolo identifikovaných 94 zahraničných empirických výskumných správ z oblasti pedagogiky a následne je formou ilustračných príkladov bližsie predstavená jedna z oblastí výskumu, a to výskumy realizované priamo v prostredí školskej triedy počas prebiehajúcej reálnej výnky. Cielom oboch častí je určité približenie témy eye-trackingu českému a slovenskému citatelovi a prostredníctvom vybraných výskumov aj ilustrovanie a dokázanie, že aj v pedagogickom výskume má eye-tracking svoje miesto.
\end{abstract}

Klúčové slová: eye-tracking, mapovanie očných pohybov, učitel', žiaci, procesy v školskej triede, prehladová śtúdia.

\section{ÚvoD}

Technológia eye-tracking je založená na princípe sledovania pohybu očí pri vnímaní obrazu. Zariadenie, ktoré je schopné tieto pohyby sledovat a merat, sa označuje ako eye-tracker. $\mathrm{V}$ českej a slovenskej pedagogickej literatúre sa $s$ technológiou eye-trackingu, tiež nazývanej aj očná kamera, čitatel' doposial' stretáva len výnimočne. Pozornost je venovaná napríklad oblasti vizuálnej percepcie učebných materiálov, ako sú učebnice alebo počítačové prezentácie (Gejdušová et al., 2015;
Labischová, 2015; Svatoš \& Maněnová, 2017), skúmaniu matematickej a logickej inteligencie u nadaných žiakov (Škrabánková \& Trnová, 2014; Škrabánková, 2016). V oblasti geografie má pomerne silné zastúpenie skúmanie percepcie máp (Popelka, Brychtová \& Voženílek, 2012; Brychtová \& Vondráková, 2014), či u geoinformatiky $\mathrm{v}$ rámci testovania kognície geografických informačných systémov (Dobešová, 2016). Spomeniem tiež oblast fyzikálneho vzdelávania, kde sa metóda eye-trackingu využíva pri skúmaní riešenia fyzikálnych úloh (Kekule, 2014a, 2014b,

\footnotetext{
${ }^{1}$ Článok vznikol v rámci riešenia projektu GA ČR Profesni viděni učitelů anglického jazyka v/po akci v komunikačnich aktivitách perspektivou eye-trackingu GA17-15467S. Autorka d’akuje za poskytnutú podporu.
} 
2015). Doposial' sa ale v našom prostredí neobjavili výskumy, ktoré by využili túto technológiu priamo v prostredí školskej triedy počas prebiehajúcej výuky.

Nasledujúci text má dve hlavné ambície. Prvou je podat českým a slovenským čitatelom určitý úvod do problematiky eye-trackingu a druhou následne priniest poznatky prehladového charakteru o zahraničných výskumoch $\mathrm{z}$ pedagogického prostredia, v ktorých autori využili práve túto technológiu.

Prvá čast prostredníctvom rozpravy o očných pohyboch poskytuje priestor na vysvetlenie toho, prečo sa naše oči hýbu, aké očné pohyby rozlišujeme a tiež čo všetko môže mat vplyv na očné pohyby.

$\mathrm{V}$ druhej kapitole sa objavuje stručný historický prehlad, následne sa pojednáva o viacerých metódach umožňujúcich sledovanie očných pohybov a tiež o možných dátových výstupoch z eye-tracking prístrojov.

Tretia kapitola predstavuje výsledky vyhladávania prác z oblasti pedagogiky, v ktorých boli použité eye-tracking prístroje. Ciel'om vyhladávania bolo identifikovat a kategorizovat konkrétne oblasti, kde našiel eye-tracking svoje využitie.

V poslednej časti tejto práce je na základe ilustračných príkladov bližšie predstavená jedna oblast' $\mathrm{z}$ predchádzajúcej kategorizácie, a to výskumy, ktoré boli realizované priamo v školskej triede. Dôvodov výberu danej špecifickej a zároveň čo do počtu najmenej obsiahlej kategórie je viacero. Prvým je obdobie vzniku, kedy sa jedná o výskumy najmladšie, ${ }^{2}$ a tak je určite zaujímavé s danými prácami čitatela oboznámit. Druhým je určitý predpoklad, že výskumy podobného charakteru môžu v budúcnosti úspešne narastat. Tento predpoklad je spojený s vývojom technológie, kedy sa eye-trackingové prístroje stávajú menšími, cenovo dostupnejšími a mobilnejšími, a tak sa znižuje obmedzenie na laboratórne použitie a je možné tieto prístroje využit aj v prostredí prirodzenom pre aktérov, $\mathrm{v}$ našom prípade $\mathrm{v}$ prostredí školskej triedy. $\mathrm{V}$ prípade, že sa bude rovnako zvyšovat dostupnost' prístrojov a širšia skupina výskumníkov $\mathrm{k}$ nim bude mat́ prístup, tak pokladám za prospešné podat určitú inšpiráciu pre výskumníkov, ktorí by mali záujem začlenit dáta $\mathrm{z}$ eye-trackingových prístrojov do ich výskumu, alebo priamo na nich celý výskum postavit'.

\section{OČNÉ POHYBY}

To, že sa naše očí hýbu, je zapríčinené znižovaním vizuálnej presnosti (ubýtok $\mathrm{v}$ hustote fotoreceptorov na sietnici) z oblasti fóvey, predstavujúcej miesto najostrejšieho videnia, do periférnej oblasti. Vyústením je nutnost pohybovat' očami aby sme si zaistili prístup k informáciám, ktoré sa nezobrazujú v mieste najostrejšieho videnia (Findlay \& Gilchrist, 2003). Naše zorné pole zaberá relatívne vel'kú plochu, ostro ale vidíme len $\mathrm{v}$ jeho strednej časti a ako sa presúvame $\mathrm{k}$ jeho okrajom, tak presnost' a ostrost postupne ubúda.

$\mathrm{Na}$ samotnom začiatku skúmania očných pohybov stála domnienka Justa

${ }^{2} \mathrm{~V}$ porovnaní s ostatnými kategóriami, kde má využitie technológie eye-tracking dlhšiu tradíciu. 
a Carpentera (1980) nazvaná tiež ako oko-mysel' (eye-mind) predpoklad, ktorá spustila záujem zahrnút eye-trackingové prístroje do mnohých výskumných oblastí. Predpoklad pracuje $s$ tézou, že pohlad zostáva fixovaný práve na tú oblast vizuálneho pola, ktorá sa v danej chvíli kognitívne spracováva. Dlížu pohladu na danú oblast' je možné použit ako ekvivalent času potrebného na spracovanie tejto informácie; to, na čo sa pozeráme, indikuje, čo $\mathrm{v}$ danej dobe spracovávame, a ako dlho na to pozeráme, zas indikuje, aké vel'ké úsilie je na toto spracovanie potrebné. V súčasnej dobe je Justov a Carpenterov predpoklad hodnotený ako príliš zjednodušujúci, nepresný a nepočítajúci s mnohými situáciami, ktoré tento predpoklad úplne nerešpektujú. Týka sa to hlavne tzv. parafoveálneho spracovania informácií (pozri Rayner, 1998), kde fovea predstavuje malú priehlbinu na sietnici, bod, kde je naše videnie najostrejšie. Podnety, ktoré nie sú priamo premietané na foveu (fixované), môžu byt' ale taktiež spracované. Napríklad, ako už naznačoval samotný Just a Carpenter, podnety z prvej fixácie, miesta, na ktoré smerujeme svoj pohlad, môžu byt' stále spracovávané a integrované $s$ informáciou získanou $\mathrm{z}$ nasledujúcej fixácie umiestnenej za prvou. A za druhé, blízke podnety, ktoré fixované neboli, alebo môžu byt spracované len do určitej miery, tak už môžu prechádzat do vy̌šsie spomenutého parafoveálneho pola. Ako ukazuje holistický model vnímania obrazového materiálu (Duchowski, 2007), experti nepotrebujú klúčovú informáciu zobrazit́ pomocou najostrejšej oblasti videnia, ale sú schopní získat informácie i zo vzdialených oblastí neostrého videnia. Oblast', z ktorej je informácia počas fixácie extrahovaná, sa nazýva percepčné rozpätie (perceptual span) a jeho šírka závisí od inštrukcií poskytnutých $\mathrm{k}$ splneniu určitej úlohy, zložitosti tejto úlohy alebo problému a taktiež individuálnych schopností a skúseností každého človeka. Výskumníci z oblasti výskumu čítania a vizuálneho vnímania scén sa zaoberajú zistovaním a mapovaním, ktoré informácie môžu byt' vybrané práve $\mathrm{z}$ percepčného rozpätia, predovšetkým z parafoveálnej oblasti, a čo presne má vplyv na rozhodnutie presunút pozornost na d'alší fixačný bod.

\subsection{Druhy očných pohybov}

Očné pohyby predstavujú základ skúmania zrakového vnímania $\mathrm{z}$ hladiska spracovávania informácií a sú pre ne charakteristické série striedajúcich sa fixácií a sakád. Fixácie sú okamihy, kedy je oko relatívne $\mathrm{v}$ pokoji, $\mathrm{v}$ statickej polohe a my sme schopní získavat informácie $\mathrm{z}$ miest, na ktoré máme zameranú pozornost́. $\mathrm{Na}$ opak sakády predstavujú rýchle pohyby očí, kedy sa oči presúvajú z jednej fixácie na d’alšiu, a na rozdiel od fixácií z pozorovanej scény pri nich nezískavame žiadne informácie. Aj počas fixácií sa ale oko jemne pohybuje a tieto pohyby označujeme ako mikrosakády alebo tras (tremor) (Schutz, Braun \& Gegenf Urtner, 2011). Ako hlavné pohyby oka teda rozlišujeme fixácie na strane jednej a sakády na strane druhej. Oko vždy vykonáva len jeden z týchto pohybov, nie je možné, aby súčasne prebiehala fixácia a sakáda. 
Informácia o sledovanom mieste textu alebo scény je zbieraná prevažne počas doby fixácie, ale taktiež aj časti sakády a mrknutia, kým ešte stále prebieha kognitívne spracovanie tejto informácie (Inhoff \& Radach, 1998; Rayner, 1998). Z toho vyplýva, že práve fixácie sú volené ako hlavné atribúty vo väčšine výskumov očných pohybov. To, ako dlho oči fixujú určitý podnet, sa taktiež líši. Miera dížky fixácie (fixation duration) môže byt' od $50 \mathrm{~ms}$ až po dobu 500 ms (Rayner, 1998). Napriek tomu, že dĺžka fixácie môže byt - a zväčša aj je - ovplyvnená dobou kognitívneho spracovania podnetu či informácie, vel'mi krátke, či naopak vel'mi dlhé fixácie môžu byt spôsobené faktormi, ktoré nemajú priamu súvislost' $s$ kognitívnou náročnostou sledovaného podnetu.

Je dôležité spomenút, že určitý čas je potrebný aj pre presunutie informácie o vizuálnom podnete priamo do vizuálneho centra v mozgu, ako udáva Reichle a Reingold (2013), táto doba predstavuje približne $60 \mathrm{~ms}$. Krátke fixácie môžu byṫ výsledkom okulomotorických chýb a nemusia tvorit dostatočný podklad pre vizuálne spracovanie. Preto sú $\mathrm{v}$ niektorých výskumoch kombinované s nasledujúcou fixáciou, alebo úplne vyradené, aby nenastávala dezinterpretácia výsledkov spôsobená zahrnutím aj takých fixácií, ktoré neboli dostatočne dlhé na kognitívne spracovanie informácie. $\mathrm{Na}$ druhú stranu, tiež príliš dlhé fixácie môžu spôsobovat problémy a je nutné ich vyradit $z$ nazbieraných dát, pretože môžu indikovat zamyslenie respondenta, kedy nespracováva informáciu príliš dlho, ale vôbec sa vizuálnym podnetom nezaoberá. Kritériá, podla ktorých sa rozhodujeme, ktoré fixácie (príliš dlhé, príliš krátke) z nazbieraných dát vyradíme, závisia od druhu testovacej úlohy a nie je jednoduché paušálne ich definovat'. Pomôct́ nám ale môže priemerná dížka fixácie u testovanej osoby, ktorú môžeme považovat' za určitý base line. Rayner (2009) uvádza, že priemerná dĺžka fixácie počas čítania potichu je 225-250 ms, pri čítaní nahlas 275-325 ms a pri sledovaní scény (videonahrávka, reálne prostredie) je priemerná dĺžka fixácie 260-330 ms. Finálne rozhodnutie o určení dĺžky, ktorú budeme ešte definovat ako fixáciu, je záležitostou každého výskumníka, oblastou výskumu, typom prístroja a typom prezentovanej úlohy.

\section{2 Čo ovplyvňuje očné pohyby}

Napriek tomu, že mechanizmus očných pohybov počas vizuálnych úloh je komplikovanejší, ako naznačuje pôvodný Justov a Carpenterov predpoklad, jedná sa stále o užitočný opis procesov, ktoré ovládajú a majú vplyv na pohyby očí. Ukazuje to aj Rayner, Pollatsek a Reichle (2003) na príklade vplyvu lingvistických faktorov, kde napríklad frekvencia a predvídatelnost́ slov, ktoré sú v texte fixované, majú priamy vplyv na dĺžku pohladu, kedže indikujú okamžité kognitívne (lingvistické) spracovanie daného slova počas sledovanej fixácie. Dížka pohladu môže teda reflektovat čas potrebný na spracovanie podnetov vo fixovanej a tiež okolitej oblasti, rovnako ako aj informácie získané z predchádzajú- 
cich fixovaných oblastí. Môže to byt teda zoskupenie nových informácií a ich integrácia s nedávno získanými informáciami a tiež už počiatočnou predchádzajúcou znalostou.

Pohyby očí sú prirodzenou reakciou na úlohy, ktoré si vyžadujú vizuálne spracovanie. Existujú ale rôzne faktory spojené práve $s$ kognitívnym spracovaním, ktoré môžu mat vplyv na distribúciu a dížku fixácií pohladu. Bližšie tieto faktory prezentuje napríklad Henderson (2003). Charakteristika stimulov a predchádzajúca vedomost či skúsenost́ podmieňuje, akým spôsobom je prezentovaný materiál alebo scéna vizuálne spracovávaná a tiež ako sa táto informácia premietne do následného spracovania.

Spracovanie výukových materiálov nepredstavuje jednoduchý proces. Napríklad viacvýznamové reprezentácie, typicky rôzne schémy a obrázky, ktorých porozumenie a celková percepcia vychádza taktiež z náročnosti úlohy, ktorá je sledovaným osobám vopred daná, a celkovej znalostnej úrovne každej z osôb. Je potrebné ešte spomenút u mladších žiakov určitý deficit v schopnosti relevantne posúdit', ktoré časti obrázku či schémy sú obsahovo relevantné, a zaistit', že informácie získané eye-trackerom nebudú ovplyvnené percepčnou nápadnostou (perceptual saliency), predstavujúcou napr. farebne výrazný prvok na obraze, hustotou ponúkaných informácií a podobne.

Vzorce očných pohybov teda môžu byt' ovplyvňované tak kognitívnou úrovňou spracovania, ako aj percepčnou. Navyše, aj ked' dížka fixácie by mala odzrkadlovat', aký objem pozornosti je pridelený fixovaným a oblastiam blízkym fixovanej oblasti, tak tento objem nemusí vyjadrovat len relevantnost podnetu, a preto pridelenie pozornosti, ale taktiež zaujímavost podnetu, jeho zložitost' alebo jednoduchost', čo v konečnom dôsledku môže viest' k odlišným interpretáciám dížky a distribúcie fixácií. Preto je dôležité výstupy z merania pohybov očí pre komplexnú interpretáciu kombinovat's inými technikami ako napríklad verbálnymi protokolmi (think-aloud protocols), ktoré môžu mat́ podobu súbežného myslenia nahlas (concurrent think-aloud), alebo vo forme retrospektívneho myslenia nahlas (retrospective think-aloud) (Elling, Lentz \& de Jong, 2012; Ericsson \& Simon, 1993; Oh, Almarode \& Tai, 2013). Taktiež môžu byt kombinované $s$ rôznymi testami porozumenia či retrospektívnymi rozhovormi, ktoré bližšie vysvetl'ujú, čo skúmaného jedinca zaujalo a ako sledovaný materiál či scénu vnímal.

Zohladnenie radšej väčšieho objemu dát a dáta od viacerých osôb než malý dátový balík od jednej osoby sa ukazuje ako vhodnejšie pre eye-trackingové štúdie. Napríklad vel'mi dlhá priemerná dĺžka trvania fixácie spolu s vel'kou priemernou dĺžkou sakády môže indikovat', že informácie boli získavané z vel'kej plochy počas každej fixácie (Rayner et al., 2003). Na druhú stranu, vel’mi dlhá priemerná dĺžka trvania fixácie spolu s krátkou priemernou dížkou sakády môžu naznačovat, že prezeraný materiál či scéna obsahujú vysokú hustotu informácií alebo si vyžadujú zložité kognitívne spracovanie (Chen et al., 2014). 
Tab. 1. Faktory vplývajúce na očné pohyby

\begin{tabular}{|c|c|c|c|}
\hline $\begin{array}{c}\text { Na strane } \\
\text { žiaka }\end{array}$ & $\begin{array}{c}\text { Forma } \\
\text { materiálu }\end{array}$ & $\begin{array}{c}\text { Lingvistické } \\
\text { parametre textu }\end{array}$ & Inštrukcie \\
\hline predchádzajúca skúsenost' & náročnost' úlohy & frekvencia slov & náročnost́ úlohy \\
\hline predchádzajúca vedomost' & percepčne nápadné prvky & predvídatel'nost' slov & poskytnutý čas \\
\hline znalostná úroveň & hustota skúmaných prvkov & & \\
\hline $\begin{array}{c}\text { schopnost' posúdit' } \\
\text { obsahovú relevantnost' }\end{array}$ & vel'kost' sledovanej plochy & & \\
\hline
\end{tabular}

\section{Metódy SLedovania POHYBU OČÍ}

Pod pojmom eye-tracking sa ukrývajú viaceré metódy, ktorými je možné sledovat’ a zachytávat pohyby očí. Medzi historicky najstaršie patria tzv. mechanické (kontaktné) metódy, ktoré sumarizuje Robinson (1963), spočívajúce $\mathrm{v}$ umiestnení bud' špeciálne vyrobenej kontaktnej šošovky so zrkadlovou plochou priamo na rohovku oka, od ktorej sa odráža následne zaznamenávaný svetelný lúč, alebo druhého typu kontaktnej šošovky, v ktorej je zabudovaná cievka, ktorej pohyb je možné merat prostredníctvom elektrického napätia generovaného v magnetickom poli. Obe metódy umožňujú vel'mi presné meranie pohybov oka, nie sú ale vel'mi príjemné pre testované osoby a tiež nie je možné označit ich ako neinvazívne.

Druhú skupinu metód tvorí elektrookulografia (EOG), založená na meraní zmien elektrického potenciálu pomocou elektród umiestnených okolo očí. Rotácia oka vyvoláva zmeny elektrického potenciálu vo svojom bezprostrednom okolí, pretože oko sa správa ako elektrický dipól so záporným pólom na sietnici a kladným pólom na rohovke. Elektródy, ktoré sú umiestnené na tvári na opačných stranách oka, sú tak pri jeho pohybe vystavené viac jednému či druhému pólu, čo následne vyvoláva meratel'nú zmenu napätia (Inhoff \& Radach, 1998). Významnou výhodou elektrookulografie je možnost' sledovania pohybu očí za rôznych svetelných podmienok a tiež so zavretými viečkami. Metóda je tak vhodná aj pre spánkové štúdie. Ako nie úplne výhodná sa ale ukazuje pri výskumoch realizovaných mimo laboratórne prostredie, kde sledované osoby môžu pocitovat' výraznú mieru diskomfortu, čo môže viest' $\mathrm{k}$ nie štandardnému správaniu.

Ako tretiu metódu eye-trackingu uvádzam $\mathrm{v}$ súčasnej dobe najpoužívanejšiu v oblasti kognitívnej psychológie, pedagogiky, reklamy a výskumoch športu, a to eye-tracking pomocou videozáznamu, kde sú pozícia oka a smer pohladu zistované bezkontaktne. Bezkontaktné (neinvazívne) metódy spočívajú v meraní viditel'ných častí oka - zrenice, hranice dúhovky a belma - a korneálneho (rohovkového) odrazu priameho lúču infračerveného svetla. Stred zrenice a odrazený lúc sa následne zaznamenáva vysokorýchlostnou kamerou a pomocou algoritmu na rozpoznávanie 
Monitor robrazujúci stimuly

na strane respondenta

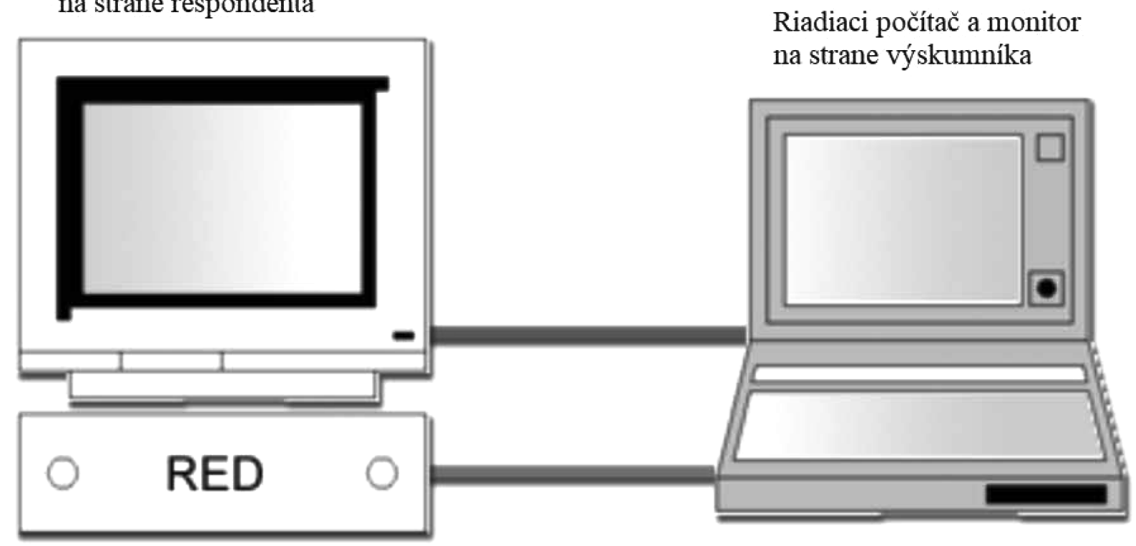

Obr. 1. Schéma systému pri použití dvoch počítačov ${ }^{3}$

obrazu sa vypočíta pohyb oka. Ako približuje Duchowski (2007), Radach a Kennedy (2004) a Rayner (1998), pomocou video eye-trackingu je možné tiež sledovat' polohu a zmeny vel'kosti zrenice, čo môže indikovat zmenu osvetlenia, ale tiež emocionality podnetov, pozornosti, vzrušenia, zátaže pracovnej pamäte a podobne.

Systém je väčšinou tvorený jedným riadiacim počítačom (na strane výskumníka), kde sú pohyby oka/očí nahrávané a monitorované, a druhým zobrazovacím počítačom (na strane respondenta), kde sú testovanej osobe prezentované experimentálne podnety (obr. 1).

Metóda video eye-trackingu sa d'alej delí ešte na dve podkategórie, vytvorené na základe polohy (statickej/dynamickej) hlavy a očí počas merania. Prvým typom sú statické tzv. desktop-mounted zariadenia, ktoré môžu byt umiestnené priamo v počítači alebo mat podobu prídavnej lišty, ktorú je možné namontovat na väčšinu bežne požívaných počítačov a laptopov (obr. 2). U tohto typu môže byt hlava fixovaná špeciálnou konštrukciou, o ktorú si testovaná osoba oprie čelo a bradu a tak sa eliminujú pohyby hlavy, čo sa často využíva pri výskumoch čítania a percepcie textu. Ak sa s touto konštrukciou nepracuje, hlava ostáva nefixovaná a musí byt použitý algoritmus, ktorý sleduje zmeny $\mathrm{v}$ polohe zreničky a taktiež celej hlavy a dáta na ich základe spracováva. Druhým typom video eye-trackerov sú tzv. head-mounted prístroje, niektorými autormi tiež nazývané ako mobilné, ktoré sú pomocou rôznych spôsobov umiestnené priamo na hlavu

${ }_{3}^{3}$ Upravené na základe schémy SensoMotoric Instruments GmbH (2009). 


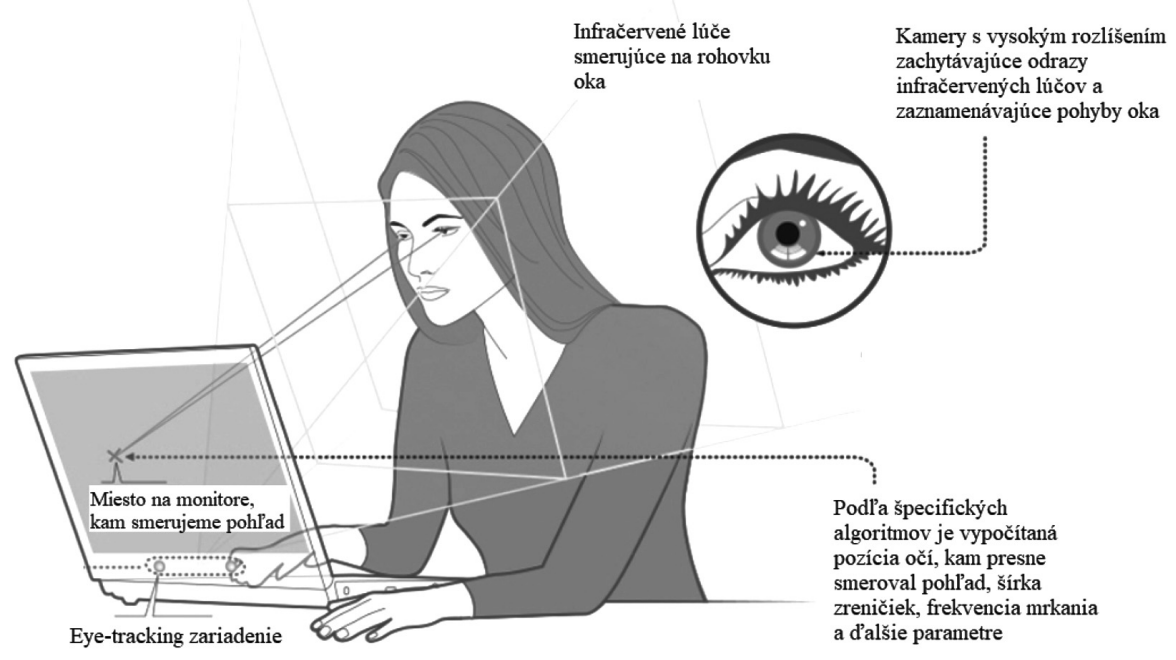

Obr. 2. Desktop-mounted zariadenie ${ }^{4}$

respondenta a tak umožňujú pohybovanie sa $\mathrm{v}$ priestore bez nutnosti fixácie $\mathrm{k}$ počítaču (obr. 3). Dáta sú prenášané káblom do počítača, prípadne mobilu, ktorý má respondent priamo u seba, alebo sú prenášané bezdrôtovo. Takéto zariadenia majú väčšinou podobu okuliarov, ktoré snímajú viacerými kamerami pohyby očí a zároveň scénu, ktorú respondent vidí zo svojho pohladu. Tieto záznamy špecializovaný software následne spája.

Výhoda mobilných eye-trackingových prístrojov spočíva $\mathrm{v}$ možnostiach ich využitia mimo laboratórne prostredie, $\mathrm{v}$ reálnych situáciách, napríklad aj počas školskej výuky, tak ako to realizovali vo svojich výskumoch Raca a Dillenbourg (2014),
Cortina et al. (2015), Dessus, Cosnefroy \& Luengo (2016) alebo Stürmer et al. (2017). Prednostou je predovšetkým neinvazívnost́ prístupu, u desktop prístrojov tiež vysoká presnost́ merania, ktorá je u mobilných prístrojov nižšia, ale na druhú stranu potenciál mobilných prístrojov tkvie $\mathrm{v}$ možnostiach aplikácie v prirodzenom prostredí.

\subsection{Dáta z eye-trackingových prístrojov}

Pred samotným meraním je potrebné vykonat kalibráciu, kde sa respondentovi prezentuje niekol'ko fixačným bodov, respondent dostane inštrukcie tieto body

\footnotetext{
${ }^{4}$ Upravené na základe schémy Tobii AB (2017).
} 


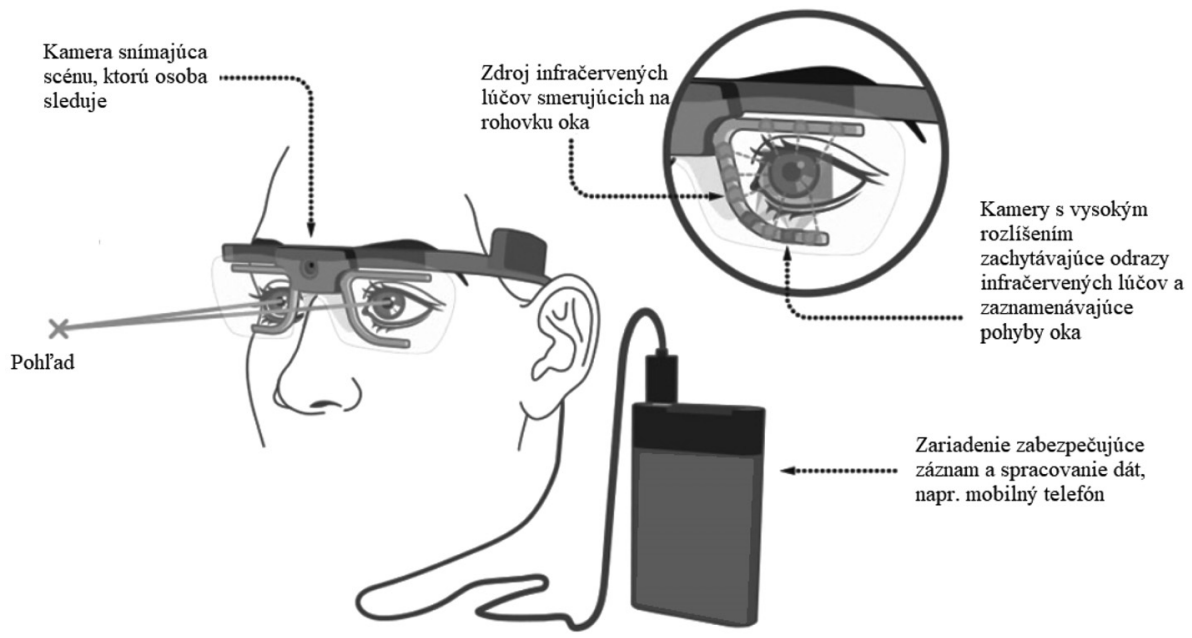

Obr. 1. Head-mounted zariadenie ${ }^{5}$

postupne sledovat a na základe testovacieho merania sa zariadenie nastaví. Poloha bodov je spravidla náhodná. Po kalibrácii nasleduje validácia, ktorá preverí presnost́ kalibrácie. Menšie odchýlky $\mathrm{v}$ nameraných hodnotách sú akceptovatel'né (spravidla $\mathrm{v}$ hodnote $0,4 \sim 1^{\circ}$ ), kritérium závisí od zvoleného prístroja a typu testovacej úlohy, o akceptácii rozhoduje samotný výskumník (Holmqvist et al., 2011).

Môže sa stat', že respondent neprejde procesom kalibrácie a následnej validácie a z merania ho musíme vylúčit. Deje sa tak na základe určitých očných vád, ked' je jedinec unavený, alebo u nositelov korekčných pomôcok zraku. Problém nastáva aj pri niektorých typoch skiel dioptrických okuliarov, kedy okrem odrazu infračerveného lúča video zachytáva aj reflexné odrazy zo skiel. Tiež u nositel'ov kontaktných šošoviek sa môžu objavit vzduchové bublinky medzi rohovkou a kontaktnou šošovkou, ktoré meranie skreslujú. Medzi problematické ešte zarad'ujeme osoby, ktoré podstúpili laserovú korekciu zraku, ich rohovka je odlišne tvarovaná - odrazený lúč môže vykazovat netypické vzorce a tak neumožňovat presné meranie. Problémy niekedy spôsobuje aj výrazný očný make-up, hrubé linky, očné tiene a očné riasy, ktoré sú zahnuté takým spôsobom, že zasahujú do oblasti oka. S danými obmedzeniami je potrebné pred začatím merania počítat, inštruovat respondentov a hlavne si byt vedomý určitých strát respondentov, ktoré je nutné zo vzorky vyradit z dôvodu neúspešnej kalibrácie a validácie.

\footnotetext{
${ }_{5}^{5}$ Upravené na základe schémy Tobii AB (2017).
} 
Tab. 2. Názvoslovie oblastí záujmu

\begin{tabular}{|c|c|}
\hline Názov & Používaná skratka \\
\hline areas of interest & AOIs \\
\hline regions of interest & ROIs \\
\hline interest areas & IAs \\
\hline look zones & LZs \\
\hline
\end{tabular}

Eye-trackingové prístroje zbierajú rozmanité množstvo dát, vo všeobecnosti je možné rozdelit ich na základe kategorizácie Holmqvista et al. (2011), Laia et al. (2013) a Radacha a Kennedyho (2004) na merania zohladňujúce priestorové, časové, frekvenčné a sekvenčné dimenzie. Priestorové a časové parametre vyjadrujú, v akej šírke zorného pol'a sa oči pohybujú, ktoré časti obrazu sú fixované a $\mathrm{v}$ akom čase sa toto odohráva. Frekvenčné parametre vyjadrujú, kolkokrát bol sledovaný bod fixovaný a po akú dlhú dobu, a napokon sekvenčné parametre slúžia na vyjadrenie vzorcov, ktoré reflektujú prechody medzi viacerými častami sledovaného materiálu alebo scény.

Vizualizovat dáta $\mathrm{z}$ eye-trackingových prístrojov je možné viacerými spôsobmi. Medzi najvyužívanejšie patrí vizuálna cesta (scan path / gaze plot / vizual path), kedy sú na zobrazovanom materiáli fixácie označené okrúhlymi oblastami, pričom priemer týchto oblastí odráža dľžku fixácie a jednotlivé fixácie sú spojené priamkami, ktoré vyjadrujú sakády.

Ďalším spôsobom je vizualizácia prostredníctvom tepelných máp (heat maps), kde je objem pohladu na jednotlivé časti scény vyjadrený zmenou farby zobrazenia na základe množstva získanej pozornosti, alebo formou tzv. ohniskových máp (focus maps), kde je objem pohladu vyjadrený zmenou transparentnosti jednotlivých stimulov. U tepelných máp najviac sledovaným podnetom program priradí napr. najteplejší odtieň farby (na základe nastavenia) a u ohniskových máp by bol takto vyhodnotený stimul zobrazený ako najjasnejší, najviac transparentný bod na sledovanej scéne. Tento typ vizualizácie sa výborne hodí pri výskumoch, kde ten istý materiál sleduje väčší počet osôb.

Cielové oblasti textu alebo scény, ktoré nás zaujímajú, sa nazývajú oblasti záujmu (areas of interest alebo regions of interest, menej často ako interest areas či look zones; tab. 2). U výskumu čítania a percepcie textu sa ako AOIs zväčša volia jednotlivé slová, u výskumov orientovaných na kognitívne náročné spracovanie potom celé vety, prípadne odstavce. Diagramy a obrázky môžu byt rozdelené na viaceré menšie segmenty tvoriace AOIs (Holmqvist et al., 2011).

\section{EYE-TRACKING}

\section{PEDAGOGICKOM VÝSKUME}

$\mathrm{Na}$ približenie oblastí pedagogického výskumu, v ktorých je možné využit technológiu eye-tracking, slúži nižšie uvedený prehlad vytvorený na základe analýzy publikácií. Kritériá pre ich vý- 
Tab. 3. Eye-tracking v pedagogickom výskume

\begin{tabular}{|c|l|c|c|c|}
\hline Oblast výskumu & $\begin{array}{c}\text { Počet } \\
\text { textov }\end{array}$ & $\begin{array}{c}\text { Príklad reprezentujúceho } \\
\text { výskumu }\end{array}$ & Poznámka \\
\hline 1 & Výskum čítania & 35 & $\begin{array}{c}\text { Mason, Pluchino } \\
\text { \& Tornatora (2015) }\end{array}$ & $\begin{array}{c}\text { Prelínanie oblasti } \\
\text { pedagogiky a psychológie }\end{array}$ \\
\hline 2 & $\begin{array}{l}\text { Učenie vo virtuálnom } \\
\text { ýukovom prostredí }\end{array}$ & 28 & Sharma et al. (2013) & \\
\hline 3 & Výuka cudzích jazykov & 16 & $\begin{array}{c}\text { Okoso, Kunze \& Kise } \\
(2014)\end{array}$ & \\
\hline 4 & $\begin{array}{l}\text { Procesy v školskej triede } \\
\text { a triedny management }\end{array}$ & 9 & Cortina et al. (2015) & \\
\hline 5 & Skúmanie pozornosti & 6 & $\begin{array}{c}\text { Roebers, Schmid } \\
\text { \& Roderer (2010) }\end{array}$ & $\begin{array}{c}\text { Prelínanie oblasti } \\
\text { pedagogiky a psychológie }\end{array}$ \\
\hline
\end{tabular}

ber boli definované nasledovne (Mareš, 2013): Zvolené boli databázy SCOPUS ${ }^{6}$ a ProQuest, ${ }^{7}$ analyzované boli recenzované plné texty písané v anglickom jazyku a ako časová jednotka roky 2010-2017. ${ }^{8}$ $\mathrm{Na}$ vyhladanie výskumov boli použité klúčové slová eye tracking, eye-tracking alebo eye movement a eye movements a zároveň education alebo learning alebo school class $\mathrm{v}$ abstrakte textov. Texty boli ohraničené oblastou education. Následné zúženie prebehlo na základe preštudovania abstraktov, kde boli z výberu vylúčené texty, u ktorých sa nejednalo o empirické štúdie alebo ktoré spadali pod inú oblast', najčastejšie oblast' medicíny a zdravotníctva. Po nastolení týchto kritérií ostalo 94 textov, ktorých tematické rozdelenie približuje tabulka 3.
Bolo vytvorených pät oblastí: 1 . výskum čítania, 2. učenie vo virtuálnom výukovom prostredí, 3 . výuka cudzích jazykov, 4. procesy v školskej triede a 5. skúmanie pozornosti. Najviac výskumov spadalo do kategórie výskumu čítania. Táto, spolu s kategóriou skúmanie pozornosti, predstavovala hraničnú kategóriu, pretože napriek prítomnosti filtra education sa do danej oblasti premietli aj texty publikované v psychologických časopisoch. Jedná sa teda o texty, ktoré je možné označit' ako pedagogické a rovnako psychologické. $\mathrm{V}$ tejto súvislosti je na mieste zamyslenie, ako presne je definovaná hranica medzi pedagogickým a psychologických výskumom, a napríklad aj v samotnej analýze výskumov by bolo určite zaujímavé v budúcnosti zrealizovat aj analýzu na základe

\footnotetext{
${ }^{6}$ Databáza odbornej recenzovanej literatúry https://www.scopus.com/home.uri

${ }^{7}$ Databáza odbornej recenzovanej literatúry http://www.proquest.com/

${ }^{8}$ Začiatočný rok 2010 bol zvolený na základe vstupu zariadenia Tobii Glasses na komerčné využitie a práve $\mathrm{v}$ danom roku sa začali objavovat prvé výskumy, kde bola využitá technológia mobilných eye-tracking okuliarov. Druhý najväčší výrobca týchto zariadení, SMI System, sa začal využívat od roku 2012 a od roku 2014 v podobe eye-tracking okuliarov.
} 
rovnakých klúčových slov, ale $\mathrm{v}$ oblasti psychológie. Je možné, že takto nastavený filter by priniesol odlišnú štruktúru a teda aj kategorizáciu textov. $\mathrm{Na}$ základe zvolených nastavení prinášam bližšie opísanú kategorizáciu piatich okruhov využitia eye-tracking technológie $\mathrm{v}$ pedagogike. Najviac priestoru je venované najviac typickej možnosti využitia eye-trackingu, a to v skúmaní čítania. Ostatné skupiny sú priblížené v stručnejšej forme.

\subsection{Výskum čítania}

Pred érou využitia technológie eye-trackingu $\mathrm{v}$ oblasti výskumu č́tania sa prevažne využívala metóda súbežného verbálneho protokolu (thinking aloud), ktorá prinášala bohatý zdroj dát o spracovaní textu. Nevýhodou je ale istá miera neprirodzeného zásahu, kde implementácie tejto metódy môže pozmenit proces samotného myslenia tým, že pozornost́ je odklonená z jednej úlohy, ktorou je čítanie textu, na komentovanie (Veenman, Van Hout-Wolters \& Afflerbach, 2006).

Eye-tracking je v tomto prípade jednoznačne menej obtažujúca a rušiaca metóda, kedže proces čítania nenarúša, participanti môžu slobodne sledovat text, presne tak, ako keby neboli podrobovaní sledovaniu pohybov ich očí. Zozbierané dáta ale poskytujú bohatý zdroj hovoriaci o množstve pridelenej pozornosti rôznym častiam textu (napríklad u čítania vedeckého textu), alebo o plynulosti samotného čítania.

Často sa využíva na určité odhalenie a hodnotenie schopnosti čítania, kedž̃e práve očné pohyby ich odzrkadlujú. Napríklad u viac skúsených a schopných čitatel'ov nachádzame kratšie trvanie fixácií, ich počet je menší, dlhšie sakády a menej regresných pohybov v texte než u detí, ktoré sa len učia čítat', osôb trpiacich poruchami čítania a celkovo menej schopných čitatel'ov (Rayner, Pollatsek \& Reichle, 2003). Prostredníctvom eye-trackingu sa ukazuje, že proces čítania vo všeobecnosti menej zdatných osôb v ćítaní v porovnaní s tými zdatnejšími vykazuje kvalitatívne podobné znaky, len $s$ nižšou formou efektivity.

Ako zdôrazňujú Paeglis, Orlovska a Bluss (2011), pri komparácii výsledkov detí s výsledkami čítania dospelých tak deti vykazujú podstatne dlhšie doby trvania fixácií, čo odkazuje, že čítanie ešte nebolo zautomatizované, a indikuje teda dlhší proces kognitívneho pracovania hlások a celých slov.

\subsection{Učenie vo virtuálnom výukovom prostredí}

Vo virtuálnom výukovom prostredí slúži technológia eye-trackingu napríklad na skoré odhalenie študentov, ktorí svoju pozornost' $\mathrm{v}$ nedostatočnej miere venujú danému výukovému materiálu. Ide o situácie $\mathrm{v}$ reálnom čase, kedy učitel' pracuje $\mathrm{v}$ triede so žiakmi za pomoci napr. MOOC kurzov a video lekcií a nie je v jeho možnosti súbežne sledovat, čomu sa žiaci venujú. Sharma, Jermann \& Dillenbourg (2014) sledovali vztah medzi predelenou pozornostou počas sledovania výukového videa a následným skóre $\mathrm{v}$ post-testu vztahujúcom sa k sledovanému videu. Odhalili 
priamu koreláciu medzi časom, ktorý pozostával z fixácií smerovaných na relevantné pole videa, a získanou hodnotou skóre $\mathrm{v}$ teste.

Inou možnostou ako implementovat eye-tracking do zlepšenia virtuálneho výukového prostredia je sledovanie užívatel'skej prívetivosti počítačového rozhrania, v ktorom sa virtuálne vzdelávanie odohráva. Autori to často argumentujú predpokladaným nárastom distančného a dial'kového štúdia, v ktorom má práve virtuálne výukové prostredie svoje nezastupitel'né miesto.

V kontexte učenia je zaujímavou oblast tzv. učebných stratégií, kedže o vzdelávacom prostredí žiakov a študentov už nie je možné uvažovat ako o prostredí čisto fyzickom (Thomas, 2013). Je teda dôležité venovat pozornost' aj tomu, aké učebné stratégie vola žiaci práve $\mathrm{v}$ tomto prostredí a aké výstupy tieto stratégie prinášajú.

\subsection{Výuka cudzích jazykov}

Výskumné štúdie spadajúce do tejto kategórie boli vybrané na základe zastrešujúcej témy - výuky cudzích jazykov. Samotná realizácia výskumov ale pozostávala predovšetkým $\mathrm{z}$ analýzy textov, $\mathrm{s}$ ktorými v rámci výuky cudzích jazykov žiaci a učitelia pracovali. Je teda možné tieto texty označit taktiež ako určitú špecifickú podkategóriu výskumu čítania a taktiež sa na úrovni použitého materiálu tieto výskumy čiastočne prelínajú $s$ podkategóriou výskumov realizovaných priamo v školskej triede, a to konkrétne $\mathrm{v}$ rámci práce žiakov s výukovými materiálmi. Pre moju kategorizáciu bolo ale tematické zaradenie výskumov primárne, a preto túto skupinu prezentujem ako samostatnú.

Obsahovo sa venujú napríklad otázke pridelenej pozornosti slovám, ktoré sú pre žiaka $\mathrm{v}$ rámci cudzieho jazyka nové, doposial' neznáme, a ako sa odzrkadluje doba trvania fixácií pridelených novému slovu do pravdepodobnosti zapamätania alebo vybavenia si daného slova (Godfroid, Boers \& Housen, 2013). Impulzom v tomto prípade bola hypotéza Richarda Schmidta (Schmidt, 1990 in Godfroid at al., 2013), ktorá hovorí o minimálnej časovej dobe, počas ktorej musí človek vizuálne fixovat' určitý podnet ( $\mathrm{v}$ tomto prípade slovo), aby si ho v budúcnosti vedel vybavit. Autori našli signifikantný vztah medzi touto časovou dobou sledovania nových slov v textovom materiáli a následným stálym zapamätaním. Využitel'nost výsledkov je možné preniest́ aj do praktickej roviny, kedy majú učitelia cudzích jazykov väčšie poznatky o efektívnosti tej ktorej zvolenej metódy pri výuke nových slov.

\subsection{Skúmanie pozornosti žiakov}

V rámci výskumu pozornosti sa sleduje napríklad proces kódovania informácií v mozgu, ktorý je ovplyvňovaný kontextom a kontextuálnymi informáciami. Práve očné pohyby počas riešenia úloh vyžadujúcich si vysoký level pozornosti indikujú mieru pozornosti im pridelenú. Naučená informácia sa lepšie vybavuje v prípade, že vybavovanie prebieha na rovnakom mieste, kde prebehol proces učenia. Roebers et al. (2010) testovali práve na základe očných 
pohybov získaných z remote eye-tracking zariadenia mieru pozornosti pridelenú určitým predmetom a ich následné vybavovanie. Testovali dve skupiny mladších a starších žiakov a cielom bolo odhalit špecifické obdobie (7-10 rokov), v ktorom sa prehlbuje schopnost́ inhibovat rozptýlenie, filtrovat rušivé faktory a pozornost sa viac sústreduje na pridelené úlohy. Ako udáva DeMarie a Ferron (2003), tak spoločne $s$ pamätovou kapacitou sa práve stratégie kódovania informácií považujú za hlavné faktory podporujúce vývojový progres pamäti a učenia v období detstva.

\subsection{Procesy prebiehajúce v školskej triede}

Tejto skupine výskumov je venovaná celá nasledujúca kapitola.

\section{Prostredie ŠKolsKeJ Triedy}

Vel'ká čast́ pedagogického výskumu je zameraná na sledovanie a snahu o pochopenie rozmanitých procesov, ktoré prebiehajú priamo $\mathrm{v}$ centre pedagogického diania, v školskej triede. Výskumníci ale narážajú na bariéry, ktoré im toto snaženie a hlavne výstupy stažujú. $V$ prípade rozhovorov s aktérmi školskej výuky, či už žiakmi, alebo učitel'mi, sú získané informácie redukované. Vedome, ked’ nám respondent niektoré skutočnosti povedat' nechce, alebo aj nevedome, ked' na nich nespomenie, alebo si ich nie je vedomý.
Výsledkom ale je ich nepostrehnutie výskumníkom. Dotazník môže eliminovat́ ostýchavost́ pri citlivých otázkach, môže byt́ anonymizovaný, ale tiež redukuje šírku získaných informácií. Ak sa výskumník rozhodne pre pozorovanie, taktiež narazí na prekážky. Kol'ko žiakom a učitel'ovi potrvá, kým ho prestanú vnímat ako rušivý element $\mathrm{v}$ ich prostredí a budú sa správat' prirodzene? Dokáže výskumník zachytit všetky situácie v triede a správne ich následne interpretovat?? Odpoved'ou môže byt sledovanie školskej triedy pomocou kamery a následná interpretácia videozáznamu. To, čo pred niekolkými rokmi nebolo možné, alebo neskôr nebolo využívané, tak v súčasnej dobe nepredstavuje žiadny výstredný nápad.

$\mathrm{V}$ nasledujúcej časti sa budem bližšie venovat jednej vybranej skupine výskumov z hlavného výberu, a to skupine „Procesy v školskej triede“ (vid" tab. 3).

Výskumy, ktoré boli realizované pomocou eye-tracking prístrojov a ako prostredie slúžila školská trieda, som zúžila na tri hlavné oblasti: práca žiakov s výukovými materiálmi počas hodiny, zapájania sa žiakov do výuky a výskumy venované školskému managementu - konkrétne paradigme učitel'-expert a učitel'-začiatočník.

V nasledujúcej časti budú bližšie predstavené tri ${ }^{9}$ vybrané výskumy, reprezentujúce vždy jednu $\mathrm{z}$ troch definovaných skupín, ktoré boli za využitia eye-tracking technológie realizované priamo v prostredí školskej triedy.

\footnotetext{
${ }_{9}$ Výber bol založený na subjektívnom posúdení, ktorý z výskumov v každej jednotlivej skupine ilustruje najlepšie možnosti aplikácie eye-tracking technológie, prezentuje podrobne metodológiu výskumu, ako aj výsledky.
} 
Tab. 4. Eye-tracking v prostredí školskej triedy

\begin{tabular}{|c|c|c|c|c|}
\hline Oblast' výskumu & Počet & Výskumy & Typ výskumu & Typ použitého eye-trackera \\
\hline \multirow{3}{*}{$\begin{array}{l}\text { práca žiakov } \\
\text { s výukovými } \\
\text { materiálmi počas } \\
\text { hodiny }\end{array}$} & \multirow{3}{*}{3} & Liu \& Shen, 2011 & experiment & statický (iView X RED) \\
\hline & & Yang et al., 2013 & $\begin{array}{l}\text { kvantitatívny } \\
\text { prístup }\end{array}$ & statický (FaceLAB 4.5) \\
\hline & & Liu, 2014 & experiment & statický (FaceLAB 4.5) \\
\hline \multirow{2}{*}{$\begin{array}{c}\text { zapájanie sa žiakov } \\
\text { do výuky }\end{array}$} & \multirow{2}{*}{2} & $\begin{array}{c}\text { Raca \& } \\
\text { Dillenbourg, } 2014\end{array}$ & $\begin{array}{l}\text { zmiešaný } \\
\text { výskumný } \\
\text { prístup } \\
\end{array}$ & okuliare (SMI Portable) \\
\hline & & $\begin{array}{l}\text { Prieto, Sharma } \\
\text { \& Dillenbourg, } \\
2015 \\
\end{array}$ & $\begin{array}{c}\text { zmiešaný } \\
\text { výskumný } \\
\text { prístup }\end{array}$ & okuliare (nešpecifikovaný) \\
\hline \multirow{4}{*}{$\begin{array}{c}\text { ŠKOLSKÝ } \\
\text { management - } \\
\text { paradigma } \\
\text { učitel'-expert } \\
\text { a učitel'-začiatočník }\end{array}$} & \multirow{4}{*}{4} & Cortina et al., 2015 & $\begin{array}{l}\text { kvantitatívny } \\
\text { prístup }\end{array}$ & okuliare (ASL Mobile) \\
\hline & & Dessus et al., 2016 & $\begin{array}{l}\text { kvantitatívny } \\
\text { prístup }\end{array}$ & $\begin{array}{c}\text { okuliare } \\
\text { (ASL Mobile Eye-GX) }\end{array}$ \\
\hline & & $\begin{array}{c}\text { McIntyre, } \\
\text { Mainhard \& } \\
\text { Klassen, } 2017\end{array}$ & $\begin{array}{l}\text { kvantitatívny } \\
\text { prístup }\end{array}$ & $\begin{array}{l}\text { okuliare (Tobii } 1.0 \\
\text { eye-tracking glasses) }\end{array}$ \\
\hline & & $\begin{array}{l}\text { Stürmer et al., } \\
2017\end{array}$ & $\begin{array}{l}\text { kvantitatívny } \\
\text { prístup }\end{array}$ & $\begin{array}{c}\text { okuliare (bližšie } \\
\text { nešpecifikovaný model) }\end{array}$ \\
\hline
\end{tabular}

\subsection{Práca žiakov s výukovými materiálmi počas hodiny}

Yang, et al. (2013) vo výskume Tracking learners' visual attention during a multimedia presentation in a real classroom demonštrovali aplikáciu eye-tracking technológie $\mathrm{v}$ prostredí školskej triedy, kde pre študentov vytvoril učitel' prezentáciu v PowerPoint formáte na tému dôvodov vyhynutia dinosaurov. Výukový materiál bol predstavený formou prezentácie, ktorá bola vyhotovená vo viacerých verziách. Na niektorých snímkach sa vyskytovala len fotografia, na iných bola doplnená o text, alebo schému spojenú $s$ textom. Výskumu sa zúčastnilo 20 študentov bakalárskych programov, z ktorých polovica študovala vedy o Zemi (earth science), niekedy označované aj ako geovedy, takže prezentovaná téma im bola blízka, a druhá polovica študovala ostatné prírodovedné obory, mimo geovied. Ako hlavné zistenia autori udávajú nasledujúce.

Čas strávený sledovaním PowerPoint snímok sa pohyboval $\mathrm{v}$ rozmedzí od $19,7 \%$ do $59,2 \%$, čo ukazuje, že študenti strávili istú dobu sledovaním niečoho iného, zväčša učitel'a. Viac času strávili sledovaním snímok, kde bol popri fotografii prítomný aj text $(43,8 \%)$, ako snímok obsahujúcich len fotografiu 
(35,1 \%). Čo je pochopitel'né, kedže $\mathrm{k}$ fotografii je potrebné pridat čas na prečítanie textu.

Priemerná dĺžka fixácií na snímkach s obrázkom a aj textom $(261 \mathrm{~ms})$ bola kratšia než na častiach obsahujúcich iba fotografiu či obrázok $(280 \mathrm{~ms})$, čo sa dá vysvetlit dlhšou dobou potrebnou na pochopenie materiálu bez textového doprovodu, ktorý má vysvetlujúcu a upresňujúcu funkciu. Zaujímavé, je, že celkový čas potrebný na prečítanie textu a následné prepojenie $s$ obrázkom či fotografiou je kratší, ako ked' sledovaná osoba nemusela čítat žiaden text a len vnímat́ obrázok. Toto zistenie môže pomôct napríklad pri vytváraní vhodných výukových materiálov.

Ďalšie zistenia sa týkali AOIs (nadpis, text a obrázok) na snímkach a ukázalo sa, že študenti len v malej miere sledovali nadpisy. Ked' bol súčasne prezentovaný obrázok a aj text, tak viac času strávili študenti v oblasti textu ako obrázku, ale priemerná dĺžka fixácií bola väčšia v AOI obrázka ako textu.

Posledná čast výsledkov spočívala $\mathrm{v}$ komparácii dát od oboch skupín študentov v odlišných študijných programoch. Študenti geovied strávili väčší čas sledovaním textu než študenti ostatných prírodovedných oborov. U obrázkov tomu bolo opačne a študenti geovied v AOIs obrázkov vykazovali menej sledovaného času.

V detailnej analýze snímok, ktoré obsahovali obrázok či fotografiu a aj text týkajúci sa možných príčin vyhynutia dinosaurov, sa ukázalo, že študenti geovied venovali viac pozornosti klúčovým pojmom v texte než študenti ostatných príro- dovedných oborov a tiež vykazovali väčšie prepájanie medzi jednotlivými AOIs.

Počas školskej výuky sú informácie prezentované viacerými formami, majú textovú a obrázkovú podobu, podobu inštrukcií a gest učitela a dôležitú úlohu zohráva taktiež interakcia medzi žiakmi či študentmi. Žiaci s odlišnou úrovňou základných znalostí sa môžu odlišovat' v spôsoboch, akými nové informácie vizuálne zachytávajú, a tak sa výskum stáva viac dimenzionálnym a komplexným.

\subsection{Zapájanie sa žiakov do výuky}

Kvalitu výuky by sme mali hodnotit na základe známok, ktoré žiaci na konci roku dostanú, a ako bude hodnotený učitel' svojim nadriadeným, alebo by bolo vhodnejšie pozriet sa na to, ako trieda počas roku spolupracovala pri získavaní nových znalostí? Uprednostňuje sa jednoznačne prvé kritérium, a to výstup a známky. Často $\mathrm{z}$ úplne pragmatických dôvodov, akými by bola prílišná komplexnost a nejednoznačnost́ takéhoto hodnotenia a čas na neho potrebný.

Raca a Dillenbourg (2014) boli týmto nápadom až tak zaujatí, že ho experimentálne overili. Cielom ich výskumu bolo pomocou viacerých videokamier umiestnených $\mathrm{v}$ triede a sledujúcich dianie z perspektívy učitela, z pohladu žiakov a taktiež za využitia mobilných eye-tracking okuliarov, zmapovat interakcie a komunikáciu medzi žiakmi navzájom a medzi učitelom a žiakmi. Výskum mal longitudinálny charakter, kde bolo sledovaných sedem výukových hodín a dáta boli kombinované s do- 
tazníkmi a rozhovormi. Učitelom prináleží nie len prezentácia výukového materiálu, musia taktiež aktívne sledovat', ako na ich výklad žiaci reagujú, a výklad potom prispôsobit. Raca a Dillenbourg túto nutnost́ prirovnávajú $\mathrm{k}$ orchestru, kde učitel' riadi celú triedu. Dáta z videonahrávok a eye-tracking okuliarov boli kombinované s dotazníkmi a rozhovormi, kde žiaci vyjadrovali, akú pozornost́ venovali učitelovi počas danej výukovej hodiny, akú mieru pozornosti venovali svojim spolužiakom, či hodnotia učitela ako aktívneho alebo skôr pasívneho, a taktiež ako vnímali výukový materiál a obsah hodiny. Tieto dáta potom porovnávali s videonahrávkami a eye-tracking dátami a boli schopní zachytit dynamiku školskej triedy a bližšie preskúmat, čo prebieha medzi žiakmi a učitelom. Približit to, čo bolo ešte donedávna považované ako nie úplne reálne. Autori tvrdia, že práve vdaka vývoju nových systémov umožňujúcich automatické zachytávanie a spracovávanie toho, čo sa počas výuky $\mathrm{v}$ hodine odohráva, budeme môct' $\mathrm{v}$ čím dalej tým väčšej miere bližšie poodhalit, ako pracuje školský „orchester“, a následne tieto poznatky preklopit aj do „nácviku budúcich dirigentov“, a tak zlepšit výuku budúcich učitelov.

\section{3 Školský management - paradigma učitel'-začiatočník a učitel'-expert}

Do tejto skupiny výskumov boli zaradené texty zamerané na školský management a väčšina $\mathrm{z}$ nich rovnako aj na problematiku tzv. profesijného videnia učitel'ov (v českom prostredí vid' Janík, Pešková \& Janík, 2014; Janík et al., 2014; Minaříková, 2014; Minař́ková et al., 2015).

Texty z výberu (Cortina et al., 2015; Dessus et al., 2016; McIntyre et al., 2017 a Stürmer et al., 2017) ukazujú, že učiteli-experti spracovávajú vizuálne informácie počas výuky rýchlejšie, ako učitelia-začiatočníci. Taktiež ich distribúcia pozornosti medzi študentov je rovnomernejšia, učitelia začiatočníci majú tendenciu venovat určitým žiakom viac a určitým naopak menej pozornosti.

$S$ nápadom skúmat rozdiely medzi učitel'mi začiatočníkmi a expertmi pomocou eye-tracking technológie prišli Yamamoto a Imai-Matsumura (2013), následne van den Bogert et al. (2014) a Wolff et al. (2016), pričom všetci používali statické eye-tracking prístroje pripevnené na obrazovku počítača a respondenti - učitelia - mali za úlohu sledovat́ nahrávky z reálnych vyučovacích hodín, zaznamenaných z pohladu učitela. Yamamoto a Imai-Matsumura (2013) zistovali schopnost' a rýchlost́ učitel'ov všimnút si nevhodné správanie a vyrušovanie žiakov. V danom výskume nezaznamenali žiadne signifikantné rozdiely medzi levelom expertízy učitel'ov a ich schopnostou postrehnút vyrušovanie žiakov. $\mathrm{V}$ podobnom duchu neskôr pokračovali van den Bogert et al. (2014), kde už ale zistili, že experti majú väčšiu tendenciu zameriavat svoju pozornost́ na následky nevhodného správania sa žiakov počas vyučovania než na samotné nevhodné správanie. Wolff et al. (2016) naopak zistili, že učitelia-experti distribuujú svoju 
pozornost menej rovnomerne a viac cielia na konkrétne miesta $\mathrm{v}$ školskej triede a sú schopní rýchlejšie spozorovat žiakov, ktorí vyrušujú, než začiatočníci, ktorým to trvá dlhšiu dobu a ich pozornost' je viac rozptýlená po priestore triedy. Nevýhodou takto koncipovaných výskumov je to, že nie úplne odrážajú správanie v prirodzených podmienkach, kedže učitelia sledovali ex post video záznam vyučovacej hodiny, neboli sami aktérmi tejto hodiny a dokonca nesledovali ani nahrávky samých seba, ale iných učitelov. Tento spôsob sledovania profesijného videnia sa tiež nazýva „on action“, teda po udalosti (Eraut, 1994).

O krok dalej sa posunula Cortina et al. (2015), ked' vo svojom výskume kombinovala dáta o vizuálnej pozornosti učitel'ov s kvalitou inštrukcií vo výuke za pomoci mobilného eye-tracking prístroja - okuliarov. Jednalo sa už o sledovanie profesijného videnia formou ,in action“ (počas udalosti). Nájdené boli odlišnosti napr. $\mathrm{v}$ tom, ako podávali učitelia spätnú väzbu žiakom. Učitelia-začiatočníci volili väčšinou diskrétnejší spôsob pomocou stíšenia hlasu, priblíženia sa $\mathrm{k}$ žiakovi, nie pred celou triedou, a experti spätnú väzbu zväčša poskytovali jednotlivým žiakom pred celou triedou. Toto potom korešpondovalo aj s vizuálnou percepciou triedy, kde učitelia,začiatočníci mali tendenciu zameriavat sa na konkrétnych žiakov, napr. pri rozhovore len $s$ jedným žiakom mu venovali plnú svoju pozornost' a prakticky nevnímali ostatných žiakov naokolo. Oproti tomu experti, ked' komunikovali s jedným žiakom, tak stále vnímali aj dianie v triede. Toto je možné vysvetlit šírkou percepčného uhlu, ktorý je u expertov širší ako u začiatočníkov, a tak dokážu učitelia-experti periférne vnímat́ aj to, čo začiatočníci nezvládnu. $\mathrm{V}$ danom výskume bola distribúcia vizuálnych fixácií meraná tzv. Gini koeficientom založeným na výsledkoch pozorovania van den Bogerta et al. (2014), ktorý zistil na základe video nahrávok, že učitelia-experti vykazujú lepší prehlad o tom, čo sa $\mathrm{v}$ triede deje. Ak sa žiakovi A dostane vel'ké množstvo pozornosti od učitela, tak sa potom prirodzene ostatným žiakom dostane $\mathrm{v}$ priemere pozornosti menej. Gini koeficient nadobúda hodnotu od 0 (všetci žiaci obdržali zo strany učitela rovnaké množstvo fixácií) po hodnotu 1, ktorá znamená, že daný študent získal všetku pozornost́ učitela (všetky fixácie) a ostatní žiaci neobdržali žiadnu. Niekto môže tvrdit', že učitel' by mal distribuovat' pozornost́ čo najviac rovnomerne medzi žiakov a len tak bude zaistený efektívny monitoring triedy (Gini koeficient 0 ). To ale zaručené byt nemusí, pretože $\mathrm{v}$ reálnej školskej triede sa líši potreba žiakov po pozornosti učitela. Dobrý učitel by mal mat tendenciu venovat viac pozornosti (Gini blížiaci sa $\mathrm{k}$ hodnote 1) žiakom, ktorí majú problém $s$ porozumením. V danom výskume je ale Gini koeficient vnímaný čisto ako miera kompetencie učitela rovnomerne monitorovat' celú triedu. Výsledky výskumu Cortiny at al. (2015) ukázali, že učitelia-začiatočníci mali vyššie hodnoty Gini koeficientu ako učitelia-experti, a teda menej zvládali rovnomerne monitorovat celú triedu. 


\section{DisKUSIA A ZÁVERY}

Linka tejto teoretickej práce viedla od vysvetlenia podstaty očných pohybov cez opísanie prístrojov slúžiacich na ich zaznamenávanie, spôsoby ich analýzy a interpretácie až po zdôvodnenia vyplývajúce z realizovaných výskumov, prečo má eye-tracking svoje miesto aj $\mathrm{v}$ rámci pedagogického výskumu.

$\mathrm{Z}$ podstaty technológie bolo ešte donedávna možné realizovat eye-trackingové výskumy výlučne v laboratórnom prostredí, čo bolo a stále aj je zaiste prínosné a využitel'né aj v oblasti pedagogiky. Vel'mi obsiahlou a významnou skupinou výskumov, ktoré je možné označit ako pedagogické a zároveň boli realizované pomocou eye-trackingu, sú výskumy čítania a percepcie textu. Táto skupina tvorí určitý základný kameň a taktiež je hlavným dôvodom, prečo ludia začali v minulosti študovat pohyb očí. Bolo tomu vdaka nie úplne jasnému mechanizmu, kedy oči vykonávajú krátke, trhané pohyby a nekopírujú priamo riadky textu tak, ako sa to kedysi očakávalo. Prostredie laboratória má ale svoje špecifiká a obmedzenia a určitým výskumným problémom prostredie limitované na laboratórium nie príliš svedčí. A to je jedným z hlavných dôvodov stojacim za vznikom tohto textu.

Už v úvode práce je spomenutý posun, kedy je vdaka technologickému progresu možné eye-tracking použit aj v prostredí prirodzenom, v teréne, akým je aj školská trieda počas prebiehajúcej výuky. Takto orientované výskumy majú v zahraničí už istú tradíciu, v českom a slovenskom pro- stredí zatial' vel'mi nie, a preto ako druhá čast textu bola zaradená prehladová štúdia výskumov zahraničných, ktoré môžu byt́ inšpiráciou aj pre českých a slovenských výskumníkov pohybujúcich sa v oblasti pedagogiky. Viaceré univerzity už disponujú eye-tracking zariadeniami a často hlavnou bariérou v ich využívaní je nie len nedostatočná technická znalost', ale aj absencia inšpirácie a určitej dobrej praxe, ktorá nám ukáže, v akých oblastiach by eye-tracking bolo možné využit a akým spôsobom môže obohatit naše dáta.

Sledovat pritom môžeme tak žiakov, ako učitel'ov, alebo ich vzájomné interakcie. Na strane žiakov ide napríklad o prácu $s$ výukovými materiálmi, pričom nie sme limitovaní len laboratórnym prostredím, ako tomu bolo pri prvých eye-trackingových prístrojov. Pri učiteloch zase sledovaním, ako si organizujú výuku, kam smeruje ich pozornost', ako zvládajú situácie náročné na zorientovanie $\mathrm{v}$ triede a podobne.

Taktiež paradigma učitel'-expert verzus učitel'-začiatočník, kde sa tento koncept prebral zo štúdií zameraných na pilotov a vodičov automobilov. Táto paradigma je v podstate aplikovatel'ná na akékolvek obory, kde sa sleduje expertíza a reagovanie expertov a začiatočníkov $\mathrm{v}$ určitých špecifických situáciách. Tak to bolo aj s inšpiráciou u vodičov (Duchowski, 2007), kde viacerí autori (Chapman \& Underwood in Duchowski, 2007) sledovali reakcie začínajúcich vodičov a ich skúsených kolegov, ktorí na špeciálne vytvorenom simulátore reagovali na nebezpečné a nečakané momenty počas jazdy autom. Paralelou je v oblasti pedagogiky sledovanie učitel'ov 
nachádzajúcich sa v rôznej miere expertízy, ako reagujú na nečakané situácie $\mathrm{v}$ triede či nedisciplinovanost žiakov. U pilotov (Ottati et al. in Duchowski, 2007) boli zistované odlišnosti $\mathrm{v}$ získavaní informácií z palubnej dosky počas letu, opät pri porovnaní jedincov s nízkou a vysokou expertízou. Aký majú dopad a využitel'nost' podobné výsledky a výstupy? Hlavne počas výuky a tréningu začiatočníkov, ked' sa pracuje s presvedčením, že experti pracujú efektívnejšie a vo väčšej miere sú schopní zachytit podstatné momenty, správne ich interpretovat' a následne reagovat. Jedná sa o dlhý proces, počas ktorého sa expertíza tvorí. Eye-trackingové zistenia ale môžu pomôct pri definovaní týchto odlišností medzi začiatočníkmi a expertmi a tak skvalitnit prípravu budúcich šoférov v autoškole, budúcich pilotov a taktiež študentov učitel'ských oborov, ktorí sa plánujú stat v budúcnosti učitel'mi.

U výskumu učitela je ale potrebné upozornit aj na určité riziká a nedostatky spojené práve s využitím eye-tracking technológie. Pri skúmaní výuky, kedy je záznam vyhotovovaný prostredníctvom mobilných eye-tracking okuliarov, by sme mali zohladnit možný rušivý element, akým tieto okuliare môžu byt'. Ich konštrukcia je relatívne subtilná, oproti bežným dioptrickým okuliarom sa predsa len jedná o masívnejšie zariadenie. Problém môže nastat tak na strane učitela, ktorý má toto zariadenie na sebe, tak aj na strane žiakov, ktorí učitel'a sledujú. U učitel'a môžeme predpokladat istú mieru vykazovania neprirodzeného správania plynúceho $s$ diskomfortu z dôvodu nového predmetu umiestneného priamo na jeho hlave a taktiež $\mathrm{z}$ dôvodu uvedomovania si, že jeho pohlad sa zaznamenáva. U žiakov je tiež možné očakávat́ určitú mieru neprirodzeného správania, kedže pri priamych interakciách $s$ učitel'om sa na jeho tvári objavuje nový predmet. Obe spomenuté riziká môžeme zmenšit a čiastočne inhibovat pomocou času, počas ktorého sú všetci aktéri výuky vystavovaní eye-tracking okuliarom. Po realizovaní viacerých vyučovacích hodín prestáva tak ako učitel' a aj žiaci vnímat toto zariadenie. Z praktickej realizácie nahrávania výuky za pomoci eye-tracking okuliarov je teda odporúčané minimálne prvú zaznamenanú vyučovaciu hodinu nebrat' v úvahu pri interpretácii dát a brat' ju ako priestor, počas ktorého si všetky zúčastnené strany mohli viac zvyknút na nový element.

Ďalším problémom u eye-tracking okuliarov by mohol byt stažený výber respondentov (učitel'ov) pri výskumoch pracujúcich $s$ paradigmou expert vs. začiatočník, kde sa pri skupine expertov častokrát vyskytujú respondenti staršieho veku, u ktorých je väčší pomer tých, ktorí využívajú okuliare ako korekčnú zrakovú pomôcku. $\mathrm{Na}$ rozdiel od kontaktných šošoviek, okuliare nie sú kompatibilné ${ }^{10}$ s eye-tracking okuliarmi a tak sa nám zužuje vzorka potenciálnych respondentov.

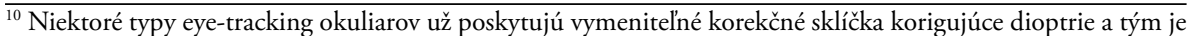
možné tento problém z časti riešit', ale zväčša ide len o určité rozmedzie dioptrií a nie je možné korigovat ostatné poruchy zraku ako napr. astigmatizmus, a tak to je vhodné pre všetkých respondentov.
} 
Aby sme dokázali relevantne interpretovat dianie v školskej triede, tak je vhodné dáta triangulovat aj $s$ inými zdrojmi. Samotné dáta $\mathrm{z}$ eye-tracking okuliarov nám síce podajú obraz o tom, čo presne $\mathrm{v}$ daný moment respondent sleduje, ak by sme ich použili ako jediný zdroj dát, tažko by sa nám interpretoval celý kontext diania. Preto je nutné do monitorovania triedy zapojit' napr. statické kamery zachytávajúce dianie aj v tých častiach triedy, ktoré aktuálne učitel' nesleduje. Ďalej, ako bolo spomenuté v kapitole 1.2., pre správnu interpretáciu dát sa zvyknú využívat verbálne protokoly zaznamenávané ex post. Dokopy, aby sme dokázali korektne interpretovat' realitu, je potrebné väčšie množstvo zariadení, náročnejšia príprava a následná analýza a výskum nutne dostáva značne komplexný charakter. Čo sa zdá byt jednoznačne zložitým postupom, ale ak zároveň prinesie nové zistenia či prehÍbenie tých známych, tak to by už mohlo byt' chápané ako relevantné odôvodnenie zapojenia tejto technológie.

Skúmanie procesov vyučovania a učenia prostredníctvom nových technológií, akou eye-tracking zaiste je, nemusí sme- rovat iba $\mathrm{k}$ inovatívnemu a rozšírenému hodnoteniu žiakov či učitelov. Nemyslím si, že jediný benefit, ktorý vzíde z takto koncipovaných pozorovaní je ohodnotenie na škále od 1 do 10 , ale ideálne by to mohlo viest $\mathrm{k}$ tomu, aby sme pomohli učitel'om identifikovat' správne postupy vo vyučovaní, žiakom správne mechanizmy ako sa efektívnejšie učit a tvorcom výukových materiálov poskytnút spätnú väzbu o tom, akú formu by výukové materiály mali mat. $\mathrm{V}$ ideálnom prípade by smerovanie malo byt čo najviac individuálne a personalizované, pretože diverzita predmetov, učitel'ov a žiakov je tak široká, že poskytnút jedno a najlepšie riešenie sa nejaví ako reálne. Preto je aj otázka dobrej, najlepšej praxe trochu otázna. Pedagogický výskum je vo vel'kej miere závislý na tom, ako sa nastaví a vymedzí vol'ba nástroja na meranie našich dát a vonkajších premenných, ktoré nie vždy dokážeme kontrolovat. $S$ každým novým technologickým posunom sa ale môžeme priblížit tomu, že dáta, ktoré pozorujeme a zbierame, čo najdôveryhodnejšie a najpresnejšie odzrkadlujú, ako interakcia medzi sledovanými osobami, prípadne osobami a výukovým materiálom prebieha.

\section{Literatura}

Brychtová A., \& Vondráková A. (2014). Green versus red: Eye-tracking evaluation of sequential colour schemes. SGEM 2014 Informatics, Geoinformatics and Remote Sensing Proceedings, 3. Cortina, K. S., Miller, K. F., McKenzie, R., \& Epstein, A. (2015). Where low and high inference data converge: validation of class assessment of mathematics instruction using mobile eye tracking with expert and novice teachers. International Journal of Science and Mathematics Education, 13(2), 389-403.

DeMarie, D., \& Ferron, J. (2003). Capacity, strategies, and metamemory: Tests of a threefactor model of memory development. Journal of Experimental Child Psychology, 84, 167-193. 
Dessus, P., Cosnefroy, O., \& Luengo, V. (2016). “Keep Your Eyes on 'em all!”: A mobile eye-tracking analysis of teachers' sensitivity to students. Adaptive and Adaptable Learning, 72-84.

Dobešová Z. (2016). Eye-tracking pro testováni ćteni workflow diagramù v geografických informačnich systémech. Sborník konference Informatika XXIX, 18.-20. 1. 2016, Luhačovice, Mendelova univerzita, Brno.

Duchowski, A. T. (2007). Eye tracking methodology: Theory and practice (2nd ed.). London: Springer.

Elling, S., Lentz, L., \& de Jong, M. (2012). Combining concurrent think-aloud protocols and eye-tracking observations: An analysis of verbalizations and silences. The IEEE Transactions on Professional Communication, 55(3), 206-220.

Eraut, M. (1994). Developing professional knowledge and competence. London: The Falmer Press.

Ericsson, K., \& Simon, H. (1993). Protocol analysis: Verbal reports as data (2nd ed.). Boston: MIT Press.

Findlay, J. M., \& Gilchrist, I. D. (2003). Active vision: The psychology of looking and seeing. New York: Oxford University Press.

Gejdušová, I., Labischová, D., \& Metelková Svobodová, R. (2015). Metody eyetrackingu ve výzkumu vizuální percepce verbálních a neverbálních textů. O dietati, jazyku, literatúre/On child, language and literature, 3(2).

Godfroid, A., Boers, F., \& Housen, A. (2013). An eye for words. Studies in Second Language Acquisition, 35(3), 483-517.

Henderson, J. M. (2003). Human gaze control during real-world scene perception. Trends in Cognitive Sciences, 7, 498-504.

Holmqvist, K., Nyström, M., Andersson, R., Dewhurst, R., Jarodzka, H., \& Van de Weijer, J. (2011). Eye tracking: A comprehensive guide to methods and measures. Oxford: Oxford University Press.

Chen, S.-C., She, H.-C., Chuang, M.-H., Wu, J.-Y., Tsai, J.-L., \& Jung, T.-P. (2014). Eye movements predict students' computer-based assessment performance of physics concepts in different presentation modalities. Computers \& Education, 74, 61-72.

Inhoff, A. W., \& Radach, R. (1998). Definition and computation of oculomotor measures in the study of cognitive processes. In G. Underwood (Ed.), Eye guidance in reading and scene per-ception (pp. 29-53). Amsterdam: Elsevier.

Janík, M., Pešková, K., \& Janík, T. (2014). Standardy pro učitelské vzdělávání jako cesta ke kvalitě: reflexe vývoje ve Spolkové republice Německo. Standardy v učitelské profesi. Orbis scholae, 8(3), 47-70.

Janík, T., Minaříková, E., Píšová, M., Kostková, K., Janík, M., \& Hublová, G. (2014b). Profesní vidění učitelů: pokus o zmapování výzkumného pole. Pedagogika, 64(2), 151-176.

Just, M. A., \& Carpenter, P. A. (1980). A theory of reading: From eye fixations to comprehension. Psychological Review, 87, 329-354. 
Kekule, M. (2014a). Students' approaches when dealing with kinematics graphs explored by eye-tracking research method In A. Bilsel \& M. U. Garip, Proceedings of the Frontiers in Mathematics and Science Education Research Conference, FISER' 2014 (108-117). Famagusta: Eastern Mediterranean University.

Kekule, M. (2014b). Výzkum pomocí oční kamery ve fyzikálním vzdělávání. Scientia in educatione, 5(2).

Kekule, M. (2015). Metoda oční kamery (eye-trackeru) při výzkumu řešení úloh z fyziky žáky SŠ a VŠ. Matematika-fyzika-informatika, 24(2).

Labischová, D. (2015). Možnosti využití metody eyetrackingu ve výzkumu kompetencí historického myšlení na př́kladu analýzy ikonografického pramene - karikatury. Pedagogická orientace. 25(2), 271--299.

Lai, M.-L., Tsai, M.-J., Yang, F.-Y., Hsu, C.-Y., Liu, T.-C., Lee, S. W.-Y., et al. (2013). A review of using eye-tracking technology in exploring learning from 2000 to 2012. Educational Research Review, 10, 90-115.

Liu, C.-J., \& Shen, M.-H. (2011). The influence of different representations on solving concentration problems at elementary school. Journal of Science Education and Technology, 20, 621-629.

Liu, P.-L. (2014). Using eye tracking to understand the responses of learners to vocabulary learning strategy instruction and use. Computer Assisted Language Learning, 27(4), 330-343.

Mareš, J. (2013). Přehledové studie: jejich typologie, funkce a způsob vytváření. Pedagogická orientace, 23(4), 427-454.

Mason, L., Pluchino, P., \& Tornatora, M. C. (2015). Eye-movement modeling of text and picture integration during reading: effects on processing and learning. Contemporary Educational Psychology, 41, 172-187

McIntyre, N. A., Mainhard, M. T., \& Klassen R. M. (2017). Are you looking to teach? Cultural, temporal and dynamic insights into expert teacher gaze. Learning and Instruction, 49, 41-53.

Minaříková, E. (2014). Profesní vidění studentů učitelství anglického jazyka: jak vidí studenti výukové situace zachycené na videu? Pedagogická orientace, 24(5), 753-777.

Minaříková, E., Píšová, M., Janík, T., \& Uličná, K. (2015). Video Clubs: EFL Teachers' selective attention before and after. Orbis scholae, 9(2), 55-75.

Oh, K., Almarode, J. T., \& Tai, R. H. (2013). An exploration of think-aloud protocols linked with eye-gaze tracking: Are they talking about what they are looking at. Procedia-Social and Behavioral Sciences, 93(21), 184-189.

Okoso, A., Kunze, K., \& Kise, K. (2014). Implicit gaze based annotations to support second language learning. Proceedings of UbiComp'14 adjunct. Dostupné z http://kaikunze.de/ papers/okoso2014implicit.pdf

Paeglis, R., Orlovska, M., \& Bluss, K. (2011). Color stabilizes textbook visual processing. In F. Baldini, J. Homola, R. A. Lieberman \& K. Kalli (Eds.), Optical sensors 2011; and photonic crystal fibers V, Prague, Czech Republic. Proceedings of SPIE, 8073, 16. 
Popelka, S., Brychtová, A., \& Voženílek, V. (2012). Eye-tracking a jeho využití při hodnocení map. Geografický časopis, 64(1), 71-87.

Prieto, L. P., Sharma, K., \& Dillenbourg, P. (2015). Studying teacher orchestration load in technology-enhanced classrooms. In G. Conole et al. (Eds.), Design for teaching and learning in a networked world (268-281). Heidelberg: Springer International Publishing.

Raca, M., \& Dillenbourg, P. (2014). Holistic analysis of the classroom. Proceedings of the 2014 ACM workshop on Multimodal Learning Analytics Workshop and Grand Challenge (13-20).

Radach, R., \& Kennedy, A. (2004). Theoretical perspectives on eye movements in reading: Past controversies, current issues, and an agenda for future research. European Journal of Cognitive Psychology, 16, 3-26.

Rayner, K. (1998). Eye movements in reading and information processing: 20 years of research. Psychological Bulletin, 124, 372-422.

Rayner, K. (2009). Eye movements and attention in reading, scene perception, and visual search. The Quarterly Journal of Experimental Psychology, 62, 1457-1506.

Rayner, K., Pollatsek, A., \& Reichle, E. D. (2003). Eye movements in reading: Models and data. Brain and Behavioral Sciences, 26, 507-526.

Reichle, E. D., \& Reingold, E. M. (2013). Neurophysiological constraints on the eye-mind link. Frontiers in Human Neuroscience, 7, 361.

Robinson, D. A. (1963). A method of measuring eye movemnent using a scieral search coil in a magnetic field. IEEE Transactions on Bio-medical Electronics, 10(4), 137-145.

Roebers, C. M., Schmid, C., \& Roderer, T. (2010). Encoding strategies in primary school children: Insights from an eye-tracking approach and the role of individual differences in attentional control. The Journal of Genetic Psychology, 171, 1-21.

SensoMotoric Instruments GmbH (2009). Experiment Center 2 Manual, Version 2.3. Dostupné z http://twiki.cis.rit.edu/

Sharma, K., Jermann, P., Nüssli, M. A., \& Dillenbourg, P. (2013). Understanding collaborative program comprehension: Interlacing gaze and dialogues. In Computer Supported Collaborative Learning (CSCL 2013).

Sharma, K., Jermann, P., \& Dillenbourg, P. (2014). How students learn using MOOCs: An eye-tracking insight. Paper presented at the EMOOCs 2014, the Second MOOC European Stakeholders Summit, Lausanne, February 10-12, 2014.

Schutz, A. C., Braun, D. I., \& Gegenf Urtner, K. R. (2011). Eye movements and perception: A selective review. Journal of Vision, 11(5).

Stürmer, K., Seidel, T., Müller, K., Häusler, J. \& Cortina, K. S. (2017). On what do pre-service teachers look while teaching? An eye-tracking study about the processes of attention within different teaching settings. Zeitschrift für Erziehungswissenschaft. Advanced online publication.

Svatoš, T., \& Maněnová, M. (2017). Learning from visual materials: A psycho-didactic experiment. Acta Technologica Dubnicae, 7(1), 43-58. 
Škrabánková, J. (2016). Practical use of the eye camera in pedagogical research. Acta Technologica Dubnicae, 6(10), 70-77.

Škrabánková, J., \& Trnová, E. (2014). Researching Students Gifted in Science Using the Method of Eye Tracking. In The 13th APFG Conference on Giftedness. Beijing: China.

Thomas, M. (2013). Technologies, innovation, and change in personal and virtual learning environments. Hershey, PA: IGI Global.

Tobii AB (2017). How do Tobii Eye Trackers work? Dostupné z www.tobiipro.com

van den Bogert, N., van Bruggen, J., Kostons, D., \& Jochems, W. (2014). First steps into understanding teachers' visual perception of classroom events. Teaching and Teacher Education, 37, 208-216.

Veenman, M. V. J., Van Hout-Wolters, B. H. A. M., \& Afflerbach, P. (2006). Metacognition and learning: Conceptual and methodological considerations. Metacognition and Learning, 1, 3-14.

Wolff, C. E., Jarodzka, H., van den Bogert, N., \& Boshuizen, H. P. A. (2016). Teacher vision: expert and novice teachers' perception of problematic classroom management scenes. Institucional Science.

Yamamoto, T., \& Imai-Matsumura, K. (2013). Teachers' gaze and awareness of students' behavior: using an eye tracker. Innovative Teaching, 2(1), 1-7.

Yang, F.-Y., Chang, C.-Y., Chien, W.-R., Chien, Y.-T., \& Tseng, Y.-H. (2013). Tracking learners' visual attention during a multimedia presentation in a real classroom. Computer \& Education, 62, 208-220.

Mgr. Zuzana Šmideková

Masarykova univerzita, Filozofická fakulta, Ústav pedagogických véd;

smidekova@phil.muni.cz 


\section{EYE-TRACKING IN THE ENVIRONMENT OF THE SCHOOL CLASS}

\section{Zuzana Šmideková}

The article presents the possibilities of use of eye-tracking technology in educational research. It combines a theoretical account of the basis and mechanism of eye movements, methods of tracking them, and finally the actual technology of eye-tracking. Then, in the second section, it builds on the results of a review study presented in two steps. First 94 foreign empirical research reports from the field of education were identified, and then one of the research fields - studies conducted directly in the classroom during real teaching, was presented in detail using illustrative examples. The aim of both sections is to familiarise the Czech and Slovak reader with the theme of eye-tracking and through selected studies to illustrate and show that eye-tracking has a place in educational research.

Key words: eye-tracking, mapping of eye movements, teacher, pupils, processes in the classroom, review study. 